\title{
Pengamatan kadar senyawa polisiklik aromatik hidrokarbon (pah): (benzo [a] pyren, benzo [a] antrasen, Benzo [b] fluoranten, di-benzo [a,h] antrasen, Dan benzo $[g, h, i]$ perylen) dalam air laut di Teluk Jakarta
}

\author{
Observation of polycyclic aromatic hydrocarbon compound (pah): benzo [a] pyrene, benzo \\ [a] anthracene, benzo [b] fluoranthene, di-benzo [a,h] anthracene, dan benzo [g,h,i] perylene \\ in seawater of Jakarta Bay
}

\section{Edward}

Pusat Penelitian Oseanografi LIPI-Jakarta

Corresponding author email: ekewe07@gmail.com

Submitted: 08 Maret 2017 / Revised: 22 Desember 2017 / Accepted: 22 Desember 2017

http://dx.doi.org/10.21107/jk.v10i2.2703

\begin{abstract}
Measurement of polycyclic aromatic hydrocarbons (PAHs) compound concentration: Benzo[a] Pyrene, Benzo[a]Anthracene, Benzo[b]Fluoranthene, Di-Benzo[a,h]Anthracene, and Benzo [g,h,i] Perylene in seawater of Jakarta Bay were carried out in March, May 2013, March and April 2011. The purpose of this research was to determined the level of pollution of the five PAH compound in seawater in relation to the protection of marine organisms. Sea water samples have taken by using a water sampler at 12 research stations. Station positions is determined by using Geographic Position System (GPS). All samples analyzed by using Gas Chromatography. The results of this research showed that the concentration of that fifth PAH compounds in seawater in March were higher compared to May and July. The content of that fifth compound has exceeded the safely threshold value for marine organism life.
\end{abstract}

Keyword: Jakarta Bay, seawater, polycyclic aromatic hydrocarbon, observation

\begin{abstract}
ABSTRAK
Pengukuran kadar senyawa polisiklik aromatik hidrokarbon (PAH): Benzo[a]Pyren, Benzo[a] Antrasen, Benzo[b]fluoranten, Di-benzo[a,h]Antrasen, dan Benzo[g,h,i]Perylen dalam air laut di Teluk Jakarta telah dilakukan pada bulan Maret, Mei 2013, Maret dan Juli 2011. Tujuannya adalah untuk menentukan tingkat pencemaran kelima senyawa PAH tersebut dalam air laut dalam kaitannya dengan perlindungan biota laut. Contoh air laut diambil dengan menggunakan alat pengambil contoh air (water sampler) di 12 stasiun penelitian. Posisi stasiun ditentukan dengan menggunakan GPS. Contoh dianalisis dengan menggunakan khromatografi gas. Hasil penelitian menunjukkan kadar ke lima senyawa tersebut pada bulan Maret lebih tinggi dibandingkan dengan Mei dan Juli. Kadar kelima senyawa tersebut telah melebihi nilai ambang batas yang aman untuk kehidupan biota laut.
\end{abstract}

Keyword: Teluk Jakarta, air laut, polisiklik aromatik hidrokarbon, pengamatan

\section{PENDAHULUAN}

Teluk Jakarta merupakan perairan estuarin, terletak di utara Jakarta dengan kedalaman rerata $\pm 15 \mathrm{~m}$, dan luas $\pm 514 \mathrm{~km}^{2}$. Ke teluk ini mengalir 13 sungai yang melintasi kota metropolitan Jakarta yang berpenduduk \pm 10 juta jiwa. Seiring dengan perkembangan kota metropolitan Jakarta sebagai ibukota negara yang semakin pesat, teluk ini juga menerima tekanan yang besar sebagai akibat dari aktivitas manusia baik di darat maupun di laut, antara lain dalam bentuk pencemaran.

Sekitar \pm 10 juta orang di kota Jakarta bertanggung jawab atas pencemaran yang terjadi di Teluk Jakarta dan sekitarnya. Seluruh limbah aktivitas manusia, baik limbah rumah tangga maupun industri, masuk ke perairan ini. Limbah tersebut mengandung berbagai macam senyawa kimia yang bersifat toksik, sehingga berbahaya bagi kehidupan 
biota laut yang hidup di Teluk Jakarta dan sekitarnya, salah satunya adalah senyawa organik polisiklik aromatik hidrokarbon (PAH).

Polisiklik Aromatik Hidrokarbon (PAH) adalah senyawa organik dengan dua atau lebih cincin benzen, bersifat toksis, karsinogen, dan mutagen (Dong et al., 2015). PAH adalah kontaminan yang menyebar secara luas di laut (NRC, 2003). PAH berasal dari sumber antropogenik seperti produksi industri, transportasi, pembakaran sampah dan proses pembakaran yang tidak sempurna seperti kebakaran hutan dan letusan gunung berapi. Kadar PAH yang dihasilkan dari proses alam umumnya lebih rendah dibandingkan dengan yang berasal dari sumber antropogenik. Zaghden et al., (2007) membagai sumber PAH dalam dalam tiga kategori: yakni 1) petrogenik, 2) pirolitik, 3) rembesan minyak alami dan diagenesis mendasarkan rasio diagnostik dan/atau dominasi congener $\mathrm{PAH}$ yang berbeda. Petrogenik PAH terkait dengan tumpahan/rembesan minyak bumi, termasuk minyak mentah dan produk olahannya. PAH biogenik dihasilkan oleh proses biologis atau tahap awal diagenesis dalam sedimen laut (misalnya perylene). PAH Pirogenik dihasilkan oleh pembakaran bahan bakar fosil (batu bara dan minyak) dan bahan organik seperti kayu (tumbuhan), (Syakti, 2016) (Stogiannidis et al., 2015)

Environment Protection Agency (EPA) menetapkan 17 jenis PAH yang bersifat toksik, karsinogen, dan mutagen terhadap biota laut dan larvanya (Mirza et al., 2012). Toksisitasnya sangat tergantung pada struktur dan isomer yang terbentuk. Diantara 17 senyawa tersebut, Benzo(a) Antrasen, Benzo(a)Pyren, Benzo[b] Fluoranten, Dibenzo(a,h)Antrasen, dan Benzo [g,h,i] Perylen masuk ke dalam kelompok senyawa yang bersifat karsinogen, mutagen dan toksik, baik terhadap manusia maupun organisme akuatik (Alawi et al., 2016). PAH memiliki toksisitas akut dengan rentang sedang sampai tinggi terhadap organisme akuatik dan burungburung (C.J. Igwee and Ukaogo, P.O. 2015). Beberapa senyawa PAH juga bersifat toksik terhadap zooplankton. Hasil uji laboratorium menunjukkan zooplankton jenis scyphozoan Pelagia noctiluca mengalami kematian $100 \%$ pada konsentrasi minyak mentah 20 and 40 $\mu \mathrm{L} / \mathrm{L}$ sesudah 16 jam (Almeda et al., 2013).

Tujuan dari penelitian ini adalah untuk mengetahui tingkat pencemaran senyawa polisiklik aromatik hidrokarbon (PAH): Benzo[a]Antrasen, Benzo[b] Flouranten, Benzo[a]Pyren, Di-benzo(a,h) Antrasen, dan Benzo[g,h,i]Perylen dalam kaitannya dengan perlindungan biota laut.

\section{MATERI DAN METODE}

Penelitian ini dilakukan di Teluk Jakarta pada bulan Maret, Mei 2013, Maret dan Juli 2011, bulan-bulan tersebut tersebut dianggap mewakili musim peralihan II dan musim timur (Gambar 1). Contoh air laut yang diambil dengan menggunakan alat pengambil contoh air (water sampler) di 12 stasiun penelitian. Semua stasiun berada di muara sungai dan dikelompokkan menjadi tiga wilayah yaitu wilayah barat (Stasiun 1, 2, 3, dan 4), wilayah tengah (stasiun 5, 6, 7, dan 8), dan timur (stasiun 9, 10, 11, dan 12). Contoh air laut (2 liter) dimasukkan ke dalam botol kaca berwarna gelap dan disimpan dalam kotak es (ice box).

Di laboratorium, contoh air laut disaring dengan kertas saring GFC (glass fiber type C) ukuran 0,45 mikron. Filtrat yang dihasilkan diekstrak dalam corong pisah dengan hexan pro analisa sebanyak tiga kali masing-masing dengan volume 100,50 , dan $5 \mathrm{ml}$. Selanjutnya filtrat dibersihkan dengan alumina WB 5 basic Sigma dan dilakukan pemisahan fraksi non polar (F1) dan polar (F2) dengan silica Merck 7754. Kadar senyawa PAH; Benzo[a]Pyren, Benzo[a]Antrasen, Benzo[b] Fluoranten, Dibenzo [a,h] Antrasen, dan Benzo[g,h,i]Perylen dalam F1 diukur dengan GC (FID) HP 5890 series II (Holden \& Marsden, 1969), Greve \& Grevenstuk (1975), Duinker \& Hillegrand (1978). Hasil pengukuran dinyatakan dalam $\mathrm{ppb}(\mu \mathrm{g} / \mathrm{l})$. 


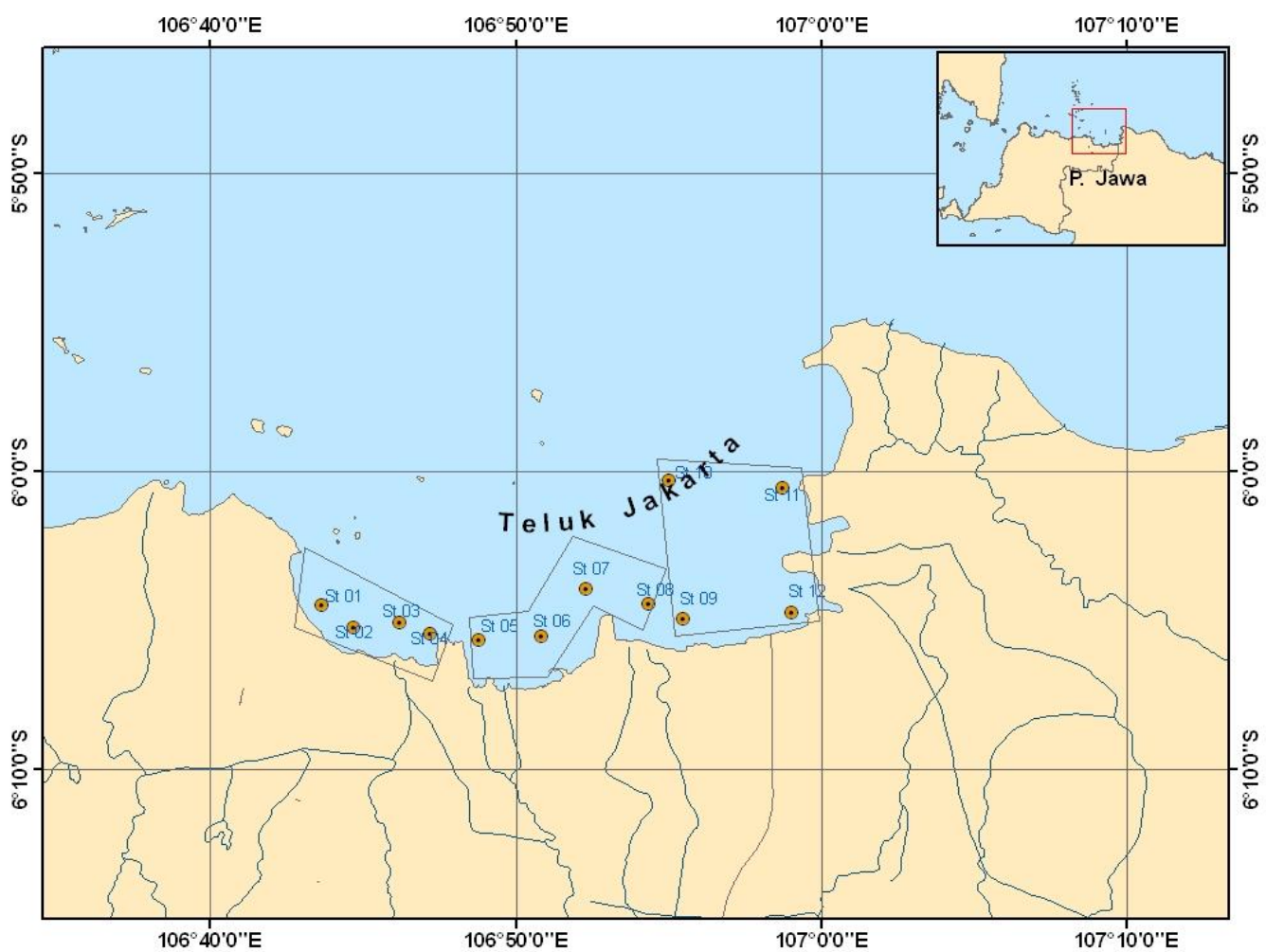

Sumber peta: Ahmad (2012).

Gambar 1. Peta Lokasi Penelitian

\section{HASIL DAN PEMBAHASAN}

Hasil pengukuran kadar senyawa Polisiklik Aromatik Hidrokarbon (PAH); Benzo(a) Antrasen, Benzo[b]Flouranten, Benzo[a]Perylen, Di-benzo(a,h)Antrasen, disajikan pada Tabel 1.

\section{Benzo(a)Antrasen, [B(a)A]}

$\mathrm{B}(\mathrm{a}) \mathrm{A}$ adalah $\mathrm{PAH}$ dengan berat molekul tinggi, terdiri dari 4 cincin benzen, dan merupakan polutan yang diprioritas oleh EPA. $\mathrm{B}(\mathrm{a}) \mathrm{A}$ terbentuk bila bahan organik seperti bensin, sampah, atau hewan/tanaman dibakar, selain itu juga ditemukan dalam rokok dan jelaga. The International Agency for
Benzo[g,h,i]Perylen dalam air laut di Teluk Jakarta bagian barat, tengah dan timur pada bulan Maret, Mei 2013, Maret dan Juli 2011

Research on Cancer (IARC), Environment Protection Agency (EPA) dan The Department of Health and Human Services (DHHS) menetapkan $\mathrm{B}(\mathrm{a}) \mathrm{A}$ sebagai senyawa yang diduga bersifat karsinogen terhadap manusia dan makhluk hidup lainnya. Paparan B(a)A dapat melalui udara, air, dan makanan (Irwin et al., 1997). Hasil pengukuran kadar B(a)A disajikan pada Tabel 1.<smiles>c1ccc2cc3cc4ccccc4cc3cc2c1</smiles>

B(a)Antrasen 
Jurnal Kelautan, 10(2), 113-128 (2017)

Tabel 1. Kadar Benzo(a)Antrasen dalam Air Laut di Teluk Jakarta, ppb, 2013

\begin{tabular}{|c|c|c|c|c|c|c|c|c|}
\hline \multirow[t]{2}{*}{ St } & \multicolumn{2}{|c|}{$\begin{array}{c}\text { Bagian Barat } \\
2013\end{array}$} & \multirow[t]{2}{*}{ St } & \multicolumn{2}{|c|}{$\begin{array}{c}\text { Bagian Tengah } \\
2013\end{array}$} & \multirow[t]{2}{*}{ St } & \multicolumn{2}{|c|}{$\begin{array}{c}\text { Bagian Timur } \\
2013\end{array}$} \\
\hline & Maret & Mei & & Maret & Mei & & Maret & Mei \\
\hline 1 & 7,892 & 4,348 & 5 & 2,671 & 1,006 & 5 & 6,276 & 0,935 \\
\hline 2 & 3,974 & 0,684 & 6 & 5,360 & 2,390 & 6 & 8,946 & 4,645 \\
\hline 3 & 5,518 & 0,641 & 7 & 14,993 & 2,988 & 7 & 11,513 & 2,865 \\
\hline 4 & 11,096 & 2,658 & 8 & 11,432 & 2,214 & 8 & 19,298 & 6,171 \\
\hline Min & 3,974 & 0,641 & Min & 2,671 & 1,006 & Min & 6,276 & 0,935 \\
\hline $\operatorname{Max}$ & 11,096 & 4,348 & $\operatorname{Max}$ & 14,993 & 2,988 & Max & 19,298 & 6,171 \\
\hline StD & 3,102 & 1,779 & StD & 5,613 & 0,831 & StD & 5,616 & 2,260 \\
\hline Rerata & 7,12 & 2,082 & Rerata & 8,614 & 2,149 & Rerata & 11,508 & 3,654 \\
\hline Total & 28,48 & 8,331 & Total & 34,456 & 8,598 & Total & 46,033 & 14,616 \\
\hline \multirow[t]{2}{*}{ St } & \multicolumn{2}{|c|}{$\begin{array}{c}\text { Bagian Barat } \\
2011\end{array}$} & St & \multicolumn{2}{|c|}{$\begin{array}{c}\text { Bagian Tengah } \\
2011\end{array}$} & \multirow[t]{2}{*}{ St } & \multicolumn{2}{|c|}{$\begin{array}{l}\text { Bagian Timur } \\
2011\end{array}$} \\
\hline & Maret & Juli & & Maret & Juli & & Maret & Juli \\
\hline 1 & 9,35 & 19,384 & 5 & 7,62 & 13,495 & 9 & 9,750 & 17,619 \\
\hline 2 & 34,69 & 14,662 & 6 & 53,92 & 15,949 & 10 & 15,57 & 17,140 \\
\hline 3 & 39,15 & 9,926 & 7 & 17,71 & 35,568 & 11 & 43,99 & 6,494 \\
\hline 4 & 60,78 & 26,905 & 8 & 25,96 & 16,532 & 12 & 15,67 & 16,466 \\
\hline Min & 9,35 & 9,926 & Min & 7,62 & 13,495 & Min & 9,750 & 6,494 \\
\hline $\operatorname{Max}$ & 60,78 & 26,905 & $\operatorname{Max}$ & 53,92 & 35,568 & Max & 43,990 & 17,619 \\
\hline StD & 21,102 & 7,239 & StD & 19,880 & 10,206 & StD & 15,413 & 5,3115 \\
\hline Rerata & 35,992 & 17,719 & Rerata & 26,302 & 20,386 & Rerata & 21,245 & 14,429 \\
\hline Total & 143,970 & 70,877 & Total & 105,21 & 81,544 & Total & 84,98 & 57,719 \\
\hline NAB B(a)A & \multirow{2}{*}{\multicolumn{8}{|c|}{0,018}} \\
\hline NAB Total PAH & & & & & & & & \\
\hline
\end{tabular}

Dari tabel 1 dapat dilihat kadar B(a)A di bagian barat Teluk Jakarta pada tahun 2013 berkisar 3,974-11,096 ppb dengan rerata 7,12 ppb dan total $28,84 \mathrm{ppb}$. Kadar ini lebih rendah bila dibandingkan dengan kadar B(a)A pada bulan Maret 2011 yang kadar B(a)A nya berkisar 9,35-60,78 ppb dengan rerata 35,992 ppb dan total $143,970 \mathrm{ppb}$. Data ini menunjukkan pada bulan Maret 2013 perairan Teluk Jakarta bagian barat menerima masukan limbah yang mengandung $\mathrm{B}(\mathrm{a}) \mathrm{A}$ lebih sedikit dibandingkan bulan Maret 2011. Keadaan yang serupa juga dijumpai pada bulan Mei 2013. Kadar B(a)A pada bulan Mei 2013 berkisar 0,641-4,348 ppb dengan rerata 2,082 ppb dan total 8,331 ppb. Kadar ini lebih rendah bila dibandingkan dengan bulan Juli 2011. Kadar B(a)A pada bulan Juli 2011 berkisar 9,926-26,905 ppb dengan total 70,877 ppb.

Di Teluk Jakarta bagian tengah pada bulan Maret 2013, kadar B(a)A berkisar 2,671$14,993 \mathrm{ppb}$ dengan rerata $8,614 \mathrm{ppb}$ dan total $34,456 \mathrm{ppb}$. Kadar ini lebih rendah bila dibandingkan dengan bulan Maret 2011. Pada bulan Maret 2011 kadar B(a)A berkisar 7,62$53,92 \mathrm{ppb}$ dengan rerata $26,303 \mathrm{ppb}$ dan total $105,21 \mathrm{ppb}$. Data ini menunjukkan bulan Maret 2013 menerima masukan limbah yang mengandung $\mathrm{B}(\mathrm{a}) \mathrm{A}$ lebih sedikit dibandingkan bulan Maret 2011. Keadaan yang serupa juga dijumpai pada bulan Mei 2013. Kadar B(a)A pada bulan Mei 2013 berkisar 1,006-2,988 ppb dengan rerata 2,149 ppb dan total 8,598 ppb. Kadar ini lebih rendah bila dibandingkan dengan bulan Juli 2011. Kadar B(a)A pada bulan Juli 2011 berkisar 13,495-35,568 ppb dengan rerata 20,386 dan total $81,544 \mathrm{ppb}$.

Di Teluk Jakarta bagian timur, pada bulan Maret 2013 kadar B(a)A berkisar 6,276-19,298 ppb dengan rerata $11,508 \mathrm{ppb}$ dan total $46,033 \mathrm{ppb}$. Kadar ini lebih rendah bila dibandingkan dengan bulan Maret 2011. Kadar B(a)A pada bulan Maret 2011 berkisar 9,750-43,990 ppb dengan rerata 21,245 ppb dan total $84,980 \mathrm{ppb}$. Keadaan yang serupa juga dijumpai pada bulan Mei 2013. Kadar B(a)A pada bulan Mei 2013 berkisar 0,935$6,171 \mathrm{ppb}$ dengan rerata $3,654 \mathrm{ppb}$ dan total $14,616 \mathrm{ppb}$. Kadar ini lebih rendah bila dibandingkan dengan bulan Juli 2011. Kadar B(a)A pada bulan Juli 2011 berkisar 6,494$17,619 \mathrm{ppb}$ dengan rerata $14,429 \mathrm{ppb}$ dan total $57,719 \mathrm{ppb}$. Data ini menunjukkan perairan Teluk Jakarta bagian timur pada bulan Maret 2013 lebih sedikit menerima masukan limbah yang mengandung $B(a) A$ dibandingkan bulan Juli 2011. 


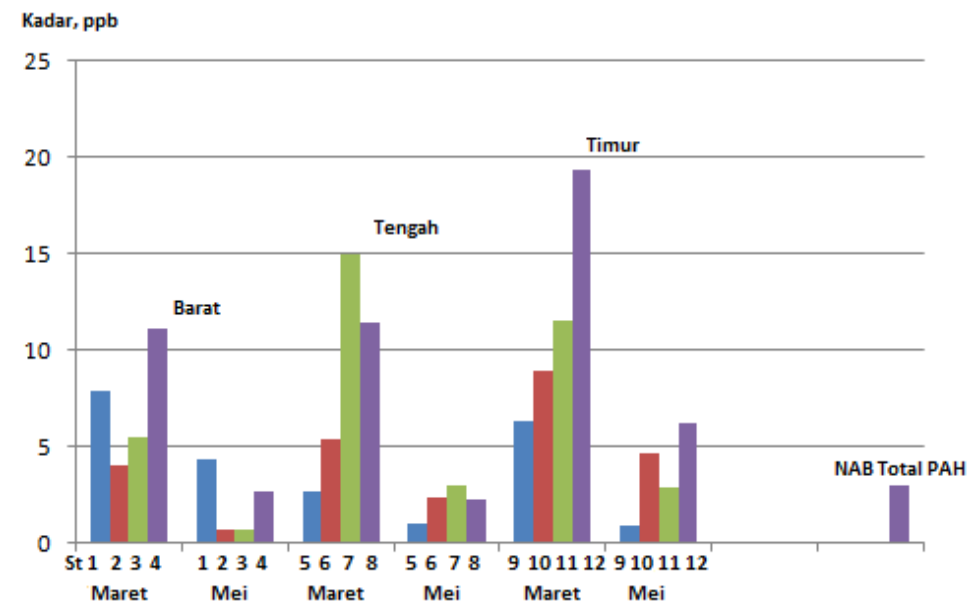

Gambar 2. Grafik Kadar B(a)A pada bulan Maret dan Mei 2013

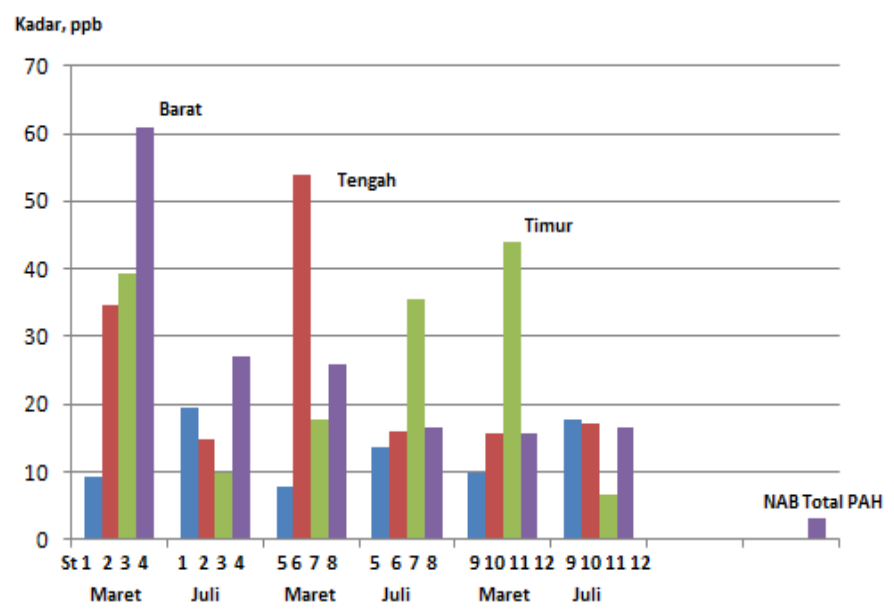

Gambar 3. Grafik Kadar B(a)A pada bulan Maret dan Juli 2011

Dari uraian di atas terlihat bahwa kadar B(a)A bervariasi baik antar stasiun maupun bulan pengamatan. Data ini juga menunjukkan bahwa volume limbah yang masuk ke Teluk Jakarta juga bervariasi setiap saat. Kadar total $\mathrm{B}(\mathrm{a}) \mathrm{A}$ ini lebih tinggi dari nilai ambang batas kadar total $\mathrm{PAH}$ yang ditetapkan KMNLH (2004) untuk perlindungan biota laut yakni 3 ppb. Environment Canada (1998) menetapkan nilai ambang batas $B(a) A$ untuk perlindungan biota laut adalah $0,018 \mathrm{ppb}$ dan $3,8 \mathrm{ppb}$ (DiToro et al., 2000). Keadaan ini dapat membahayakan kehidupan biota laut, mengingat $B(a) A$ dapat terakumulasi dalam tubuh organisme perairan.

\section{Benzo(b)Fluorantene, [B(b)F]}

$\mathrm{B}(\mathrm{b}) \mathrm{F}$ adalah senyawa $\mathrm{PAH}$ berat molekul tinggi dengan 5 cincin benzen, merupakan polutan yang diprioritaskan oleh EPA (Environment Protection Agency), dan dimasukkan kedalam kelompak polutan yang bersifat karsinogen terhadap manusia dan hewan. $B(b) F$ dihasilkan dari pembakaran yang tidak sempurna bahan bakar fosil, sampah, dalam asap rokok, bahan organik, batu bara, asap, kreosot (pengawet kayu).<smiles>c1ccc2c(c1)-c1cccc3c1c-2cc1ccccc13</smiles>

Benzo(b)Fluoranten 
Hasil pengukuran kadar $\mathrm{B}(\mathrm{b}) \mathrm{F}$ disajikan pada Tabel 2. Dari tabel tersebut dapat dilihat pada bulan Maret di Teluk Jakarta bagian barat kadar $\mathrm{B}(\mathrm{b}) \mathrm{F}$ berkisar 1,836-6,763 ppb dengan rerata $4,337 \mathrm{ppb}$ dan total $17,351 \mathrm{ppb}$. Kadar ini lebih rendah bila dibandingkan dengan bulan Maret 2011. Pada bulan Maret 2011 kadar B(b)F berkisar 37,290-212,65 ppb dengan reratan 86,845 ppb dan total 347,380 ppb. Data ini menunjukkan pada bulan Maret 2013 perairan Teluk Jakarta bagian barat ini lebih sedikit menerima masukan limbah yang mengandung $\mathrm{B}(\mathrm{b}) \mathrm{F}$.

Pada bulan Mei 2013, kadar B(b)F berkisar 0,894-2,04 ppb dengan rerata 1,501 ppb dan total 6,007 ppb, kadar ini lebih rendah bila dibandingkan dengan bulan Juli 2011 yang kadar B(b)F nya berkisar 15,608-42,851 ppb dengan rerata $29,246 \mathrm{ppb}$ dan total 117,704 ppb. Data ini menunjukkan bulan Juli 2011 lebih banyak menerima masukan limbah yang mengandung $\mathrm{B}(\mathrm{b}) \mathrm{F}$ dibandingkan bulan Mei 2013.

Di bagian tengah Teluk Jakarta pada bulan Maret 2013 kadar B(b)F berkisar 1,76-5,612 ppb dengan rerata 1,328 ppb dan total 13,635 $\mathrm{ppb}$. Kadar ini lebih rendah dari bulan Maret 2011, yang kadar $B(b) F$ nya berkisar 6,740$69,800 \mathrm{ppb}$ dengan rerata $37,995 \mathrm{ppb}$ dan total $151,980 \mathrm{ppb}$. Data ini menunjukkan bulan Maret 2013 lebih sedikit menerima masukan limbah yang mengandung $\mathrm{B}(\mathrm{b}) \mathrm{F}$ dibandingkan bulan Maret 2011. Pada bulan Mei 2013, kadar $\mathrm{B}(\mathrm{b}) \mathrm{F}$ di Teluk Jakarta bagian tengah berkisar 0,689-1,82 ppb dengan rerata 1,328 ppb dan total $5,312 \mathrm{ppb}$. Kadar ini lebih rendah bila dibandingkan dengan bulan Juli 2013 yang kadar $B(b) F$ nya berkisar 15,151$52,691 \mathrm{ppb}$ dengan rerata $35,798 \mathrm{ppb}$ dan total $142,195 \mathrm{ppb}$. Data ini menunjukkan bulan Mei 2013 lebih sedikit menerima masukan limbah yang mengandung $\mathrm{B}(\mathrm{b}) \mathrm{F}$ dibandingkan bulan Juli 2011.

Tabel 2. Kadar Benzo(b)Fluoranten dalam Air Laut di Teluk Jakarta, ppb

\begin{tabular}{|c|c|c|c|c|c|c|c|c|}
\hline \multirow[t]{2}{*}{ St } & \multicolumn{2}{|c|}{$\begin{array}{c}\text { Bagian Barat } \\
2013\end{array}$} & \multirow[t]{2}{*}{ St } & \multicolumn{2}{|c|}{$\begin{array}{c}\text { Bagian Tengah } \\
2013\end{array}$} & \multirow[t]{2}{*}{ St } & \multicolumn{2}{|c|}{$\begin{array}{c}\text { Bagian Timur } \\
2013\end{array}$} \\
\hline & Maret & Mei & & Maret & Mei & & Maret & Mei \\
\hline 1 & 5,297 & 2,040 & 5 & 1,760 & 0,689 & 9 & 17,402 & 0,677 \\
\hline 2 & 1,836 & 0,894 & 6 & 3,477 & 1,167 & 10 & 6,637 & 4,000 \\
\hline 3 & 3,455 & 1,076 & 7 & 5,612 & 1,820 & 11 & 107,844 & 1,495 \\
\hline 4 & 6,763 & 1,997 & 8 & 2,804 & 1,636 & 12 & 19,416 & 5,218 \\
\hline Min & 1,836 & 0,894 & Min & 1,76 & 0,689 & Min & 6,637 & 0,677 \\
\hline Max & 6,763 & 2,04 & $\operatorname{Max}$ & 5,612 & 1,82 & $\operatorname{Max}$ & 107,844 & 5,218 \\
\hline StD & 2,147 & 0,601 & StD & 1,627 & 0,507 & StD & 47,015 & 2,120 \\
\hline Rerata & 4,337 & 1,501 & Rerata & 3,413 & 1,328 & Rerata & 37,824 & 2,847 \\
\hline Total & 17,351 & 6,007 & Total & 13,653 & 5,312 & Total & 151,299 & 11,39 \\
\hline \multirow[t]{2}{*}{ St } & \multicolumn{2}{|c|}{$\begin{array}{c}\text { Bagian Barat } \\
2011\end{array}$} & St & \multicolumn{2}{|c|}{$\begin{array}{c}\text { Bagian Tengah } \\
2011\end{array}$} & St & \multicolumn{2}{|c|}{$\begin{array}{c}\text { Bagian Timur } \\
2011\end{array}$} \\
\hline & Maret & Juli & & Maret & Juli & & Maret & Juli \\
\hline 1 & 104,65 & 32,291 & 5 & 28,56 & 52,691 & 9 & 27,03 & 38,790 \\
\hline 2 & 121,65 & 42,851 & 6 & 69,80 & 38,554 & 10 & 31,32 & 60,306 \\
\hline 3 & 37,29 & 26,954 & 7 & 6,740 & 15,151 & 11 & 97,44 & 12,014 \\
\hline 4 & 83,79 & 15,608 & 8 & 46,880 & 36,799 & 12 & 40,59 & 12,849 \\
\hline Min & 37,29 & 15,608 & Min & 6,740 & 15,151 & Min & 27,03 & 12,014 \\
\hline Max & 121,65 & 42,851 & Max & 69,800 & 52,691 & $\operatorname{Max}$ & 97,44 & 60,306 \\
\hline StD & 36,484 & 11,335 & StD & 26,810 & 15,494 & StD & 32,723 & 23,162 \\
\hline Rerata & 86,845 & 29,426 & Rerata & 37,995 & 35,798 & Rerata & 49,095 & 30,989 \\
\hline Total & 347,380 & 117,704 & Total & 151,980 & 143,195 & & 196,38 & 123,959 \\
\hline NAB B(b)F & \multirow{2}{*}{\multicolumn{8}{|c|}{ טשואנדו }} \\
\hline NAB Total PAH & & & & & & & & \\
\hline
\end{tabular}




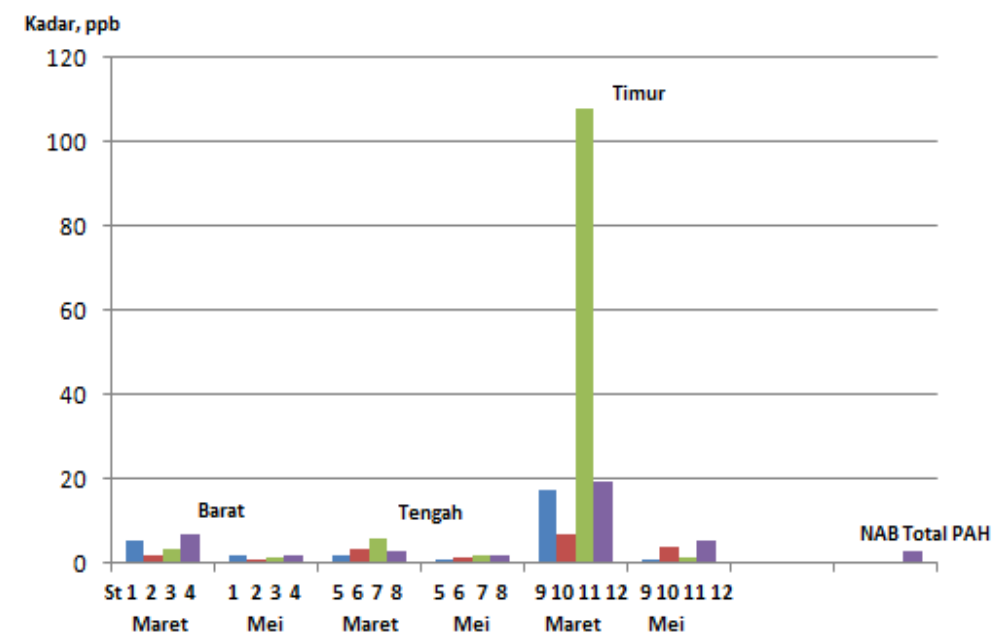

Gambar 4. Grafik Kadar B(b)F pada bulan Maret dan Mei 2013

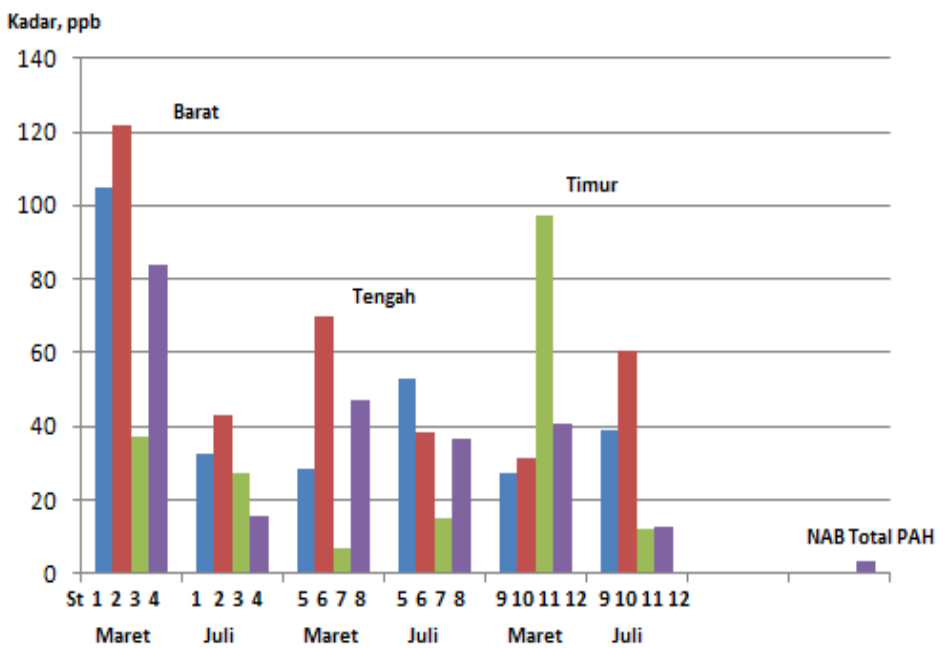

Gambar 4. Grafik Kadar B(b)F pada bulan Maret dan Juli 2011

Di Teluk Jakarta bagian timur pada bulan Mei kadar $\mathrm{B}(\mathrm{b}) \mathrm{F}$ berkisar $0,677-5,218 \mathrm{ppb}$ dengan rerata 2,847 ppb dan total 11,39 ppb. Kadar ini lebih rendah bila dibandingkan dengan bulan Juli 2011. Kadar B(b)F pada bulan Juli 2011 berkisar 27,030-97,440 ppb dengan rerata $49,095 \mathrm{ppb}$ dan total $196,380 \mathrm{ppb}$. Data ini menunjukkan bulan Mei 2013 lebih sedikit menerima masukan limbah yang mengandung B(b)F dibandingkan bulan Juli 2011.

Dari Tabel 2 di atas terlihat bahwa kadar $\mathrm{B}(\mathrm{b}) \mathrm{F}$ bervariasi baik antar stasiun maupun bulan pengamatan. Data ini juga menunjukkan bahwa volume limbah yang masuk ke Teluk Jakarta juga bervariasi setiap saat. Kadar total $\mathrm{B}(\mathrm{b}) \mathrm{F}$ ini lebih tinggi dari nilai ambang batas kadar total $\mathrm{PAH}$ yang ditetapkan $\mathrm{KMNLH}$ (2004) untuk perlindungan biota laut yakni 3 ppb dan 1,1 ppb untuk individual B(b)F (Ditoro et al., 2000). Keadaan ini dapat membahayakan kehidupan biota laut, mengingat $\mathrm{B}(\mathrm{b}) \mathrm{F}$ juga dapat terakumulasi dalam tubuh organisme perairan. Dari tabel di atas juga dapat dilihat, kadar $\mathrm{B}(\mathrm{b}) \mathrm{F}$ pada bulan Maret 2011 lebih tinggi dibandingkan dengan bulan Maret 2013, demikian bulan Juli 2011 lebih tinggi dibandingkan bulan Mei 2013. Data ini menunjukkan bahwa air laut pada Maret dan Juli 2011 lebih banyak menerima masukan limbah yang mengandung $\mathrm{B}(\mathrm{b}) \mathrm{F}$ dibandingkan dengan bulan Maret dan Mei 2013.

\section{Benzo(a)Pyren, [B(a)P]}

Benzo(a)Pyren adalah senyawa hidrokarbon aromatik polisiklik (PAH) dengan 6 cincin benzen, dihasilkan pembakaran tidak sempurna bahan organik seperti, rokok, bensin, dan kayu. B(a)P umumnya ditemukan bersama-sama dengan PAH lainnya dalam asap rokok, dalam makanan yang dibakar, dan produk dari banyak industri. Bersifat 
karsinogen terhadap manusia dan organsime akuatik. Hasil pengukuran kadar B(a)P disajikan pada Tabel 3.

Dari tabel tersebut dapat dilihat pada bulan Maret di Teluk Jakarta bagian barat kadar $\mathrm{B}(\mathrm{a}) \mathrm{P}$ berkisar 0,0-6,289 ppb dengan rerata $2,134 \mathrm{ppb}$ dan total 8,537 ppb. Kadar ini lebih rendah bila dibandingkan dengan bulan Maret 2011 yang kadar $\mathrm{B}(\mathrm{a}) \mathrm{P}$ nya berkisar 53,17171,55 dengan rerata 115,805 ppb dengan rerata 463,22 ppb. Data ini menunjukkan bulan Maret 2013 lebih sedikit mendapat masukan limbah yang mengandung $B(a) P$ dibandingkan bulan Maret 2011.<smiles>c1ccc2c(c1)cc1ccc3cccc4ccc2c1c34</smiles>

B(a)Pyren

Dari tabel tersebut dapat dilihat pada bulan Maret di Teluk Jakarta bagian barat kadar $\mathrm{B}(\mathrm{a}) \mathrm{P}$ berkisar 0,0-6,289 ppb dengan rerata 2,134 ppb dan total 8,537 ppb. Kadar ini lebih rendah bila dibandingkan dengan bulan Maret 2011 yang kadar $\mathrm{B}(\mathrm{a}) \mathrm{P}$ nya berkisar berkisar
$53,17-171,55$ dengan rerata 115,805 ppb dengan rerata 463,22 ppb. Data ini menunjukkan bulan Maret 2013 lebih sedikit mendapat masukan limbah yang mengandung $\mathrm{B}(\mathrm{a}) \mathrm{P}$ dibandingkan bulan Maret 2011.

Tabel 3. Kadar Benzo(a)Pyren dalam Air Laut di Teluk Jakarta, ppb

\begin{tabular}{|c|c|c|c|c|c|c|c|c|}
\hline \multirow[t]{2}{*}{ St } & \multicolumn{2}{|c|}{$\begin{array}{c}\text { Bagian Barat } \\
2013\end{array}$} & \multirow[t]{2}{*}{ St } & \multicolumn{2}{|c|}{$\begin{array}{c}\text { Bagian Tengah } \\
2013\end{array}$} & \multirow[t]{2}{*}{ St } & \multicolumn{2}{|c|}{$\begin{array}{c}\text { Bagian Timur } \\
2013\end{array}$} \\
\hline & Maret & Mei & & Maret & Mei & & Maret & Mei \\
\hline 1 & 6,289 & 3,062 & 5 & 0,477 & 0,940 & 9 & 21,753 & 0,911 \\
\hline 2 & 0 & 0,000 & 6 & 0 & 1,618 & 10 & 9,472 & 5,638 \\
\hline 3 & 0,600 & 1,408 & 7 & 8,787 & 2,658 & 11 & 123,396 & 1,983 \\
\hline 4 & 1,648 & 2,869 & 8 & 4,844 & 2,394 & 12 & 18,633 & 4,934 \\
\hline Min & 0 & 0 & Min & 0 & 0,94 & Min & 9,472 & 0,911 \\
\hline $\operatorname{Max}$ & 6,289 & 3,062 & $\operatorname{Max}$ & 8,787 & 2,658 & Max & 123,396 & 5,638 \\
\hline StD & 2,852 & 1,428 & StD & 4,128 & 0,778 & StD & 53,642 & 2,277 \\
\hline Rerata & 2,134 & 1,834 & Rerata & 3,527 & 1,902 & Rerata & 43,313 & 3,366 \\
\hline Total & 8,537 & 7,339 & Total & 14,108 & 7,61 & Total & 173,254 & 13,466 \\
\hline \multirow[t]{2}{*}{ St } & \multicolumn{2}{|c|}{$\begin{array}{c}\text { Bagian Barat } \\
2011\end{array}$} & $\mathrm{St}$ & \multicolumn{2}{|c|}{$\begin{array}{c}\text { Bagian Tengah } \\
2011\end{array}$} & St & \multicolumn{2}{|c|}{ Bagian Timur 2011} \\
\hline & Maret & Juli & & Maret & Juli & & Maret & Juli \\
\hline 1 & 137,04 & 32,599 & 5 & 29,93 & 74,483 & 9 & 26,060 & 59,482 \\
\hline 2 & 171,55 & 56,801 & 6 & 85,41 & 64,805 & 10 & 29,150 & 83,626 \\
\hline 3 & 53,17 & 36,007 & 7 & 51,24 & 24,535 & 11 & 93,030 & 16,482 \\
\hline 4 & 101,46 & 114,644 & 8 & 44,45 & 64,815 & 12 & 41,040 & 44,332 \\
\hline Min & 53,17 & 32,599 & Min & 29,93 & 24,535 & Min & 26,060 & 16,482 \\
\hline $\operatorname{Max}$ & 171,55 & 114,644 & Max & 85,41 & 74,483 & Max & 93,030 & 83,626 \\
\hline StD & 50,620 & 37,959 & StD & 23,513 & 22,222 & StD & 31,150 & 28,120 \\
\hline Rerata & 115,805 & 60,012 & Rerata & 52,757 & 57,1595 & Rerata & 47,320 & 50,980 \\
\hline $\begin{array}{c}\text { Total } \\
\text { NAB B }(\mathrm{a}) \mathrm{P} \\
\text { NAB Total PAH }\end{array}$ & \multicolumn{8}{|c|}{$\begin{array}{c}0,01 \\
3\end{array}$} \\
\hline
\end{tabular}


Pada bulan Mei 2013 kadar B(a)P berkisar 0,94-2,658 ppb dengan rerata $1,902 \mathrm{ppb}$ dan total 7,61 ppb. Kadar ini lebih rendah dibandingkan dengan bulan Juli 2011 yang kadar B(a)P nya B(a)P berkisar 24,535-74,483 ppb dengan rerata $57,195 \mathrm{ppb}$ dan total $228,6385 \mathrm{ppb}$. Data ini menunjukkan bulan Mei menerima masukan limbah yang mengandung $\mathrm{B}(\mathrm{a}) \mathrm{P}$ lebih sedikit dibandingkan bulan Juli 2011.

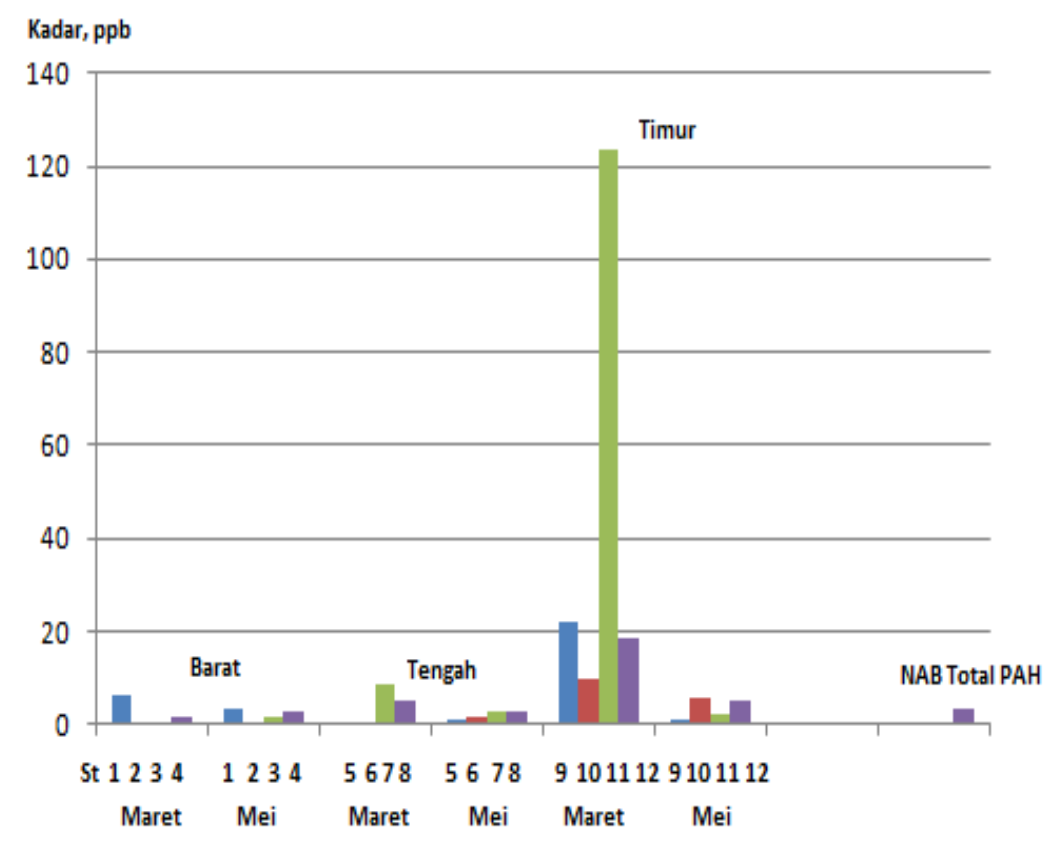

Gambar 5. Grafik Kadar B(a)P pada bulan Maret dan Mei 2013

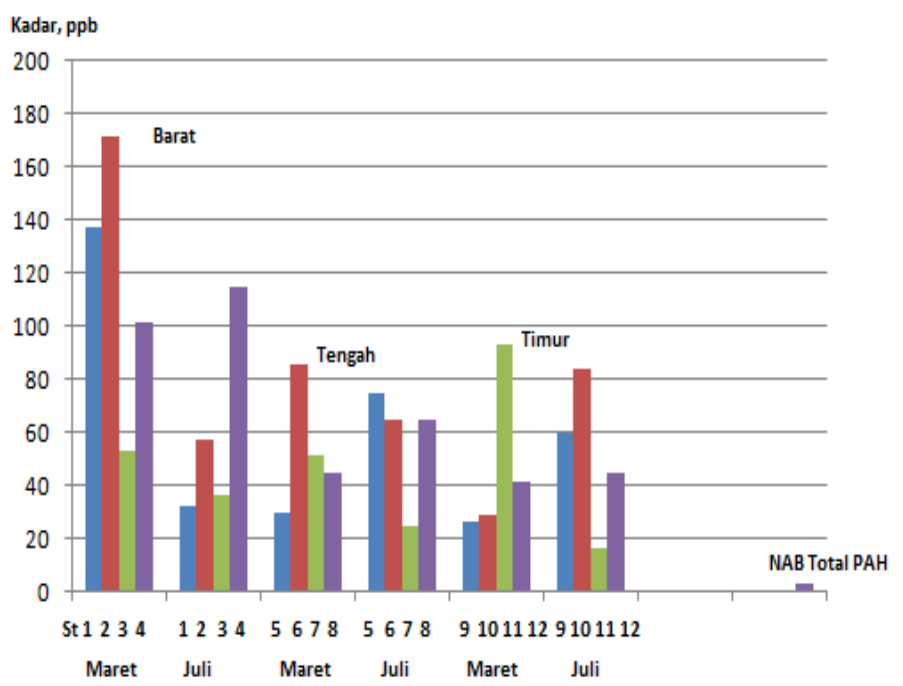

Gambar 6. Grafik Kadar B(a)P pada bulan Maret dan Mei 2011

Di Teluk Jakarta timur pada bulan Maret kadar $\mathrm{B}(\mathrm{a}) \mathrm{P}$ berkisar 9,472-123,396 ppb dengan rerata $43,313 \mathrm{ppb}$ dan total $173,254 \mathrm{ppb}$. Kadar ini juga lebih rendah dibandingkan dengan bulan Maret 2011 yang kadar B(a)P nya berkisar 26,060-93,030 ppb dengan rerata $47,320 \mathrm{ppb}$ dan total $189,280 \mathrm{ppb}$. Data ini menunjukkan bulan Maret 2013 lebih sedikit menerima masukan limbah yang menagndung B(a)P dibandingkan bulan Juli 2011.
Pada bulan Mei 2013 kadar B(a)P berkisar 0,911-5,638 ppb dengan rerata 3,366 ppb dan total $13,466 \mathrm{ppb}$. Kadar ini juga lebih kecil dibandingkan dengan bulan Juli 2013 yang kadar B(a)P nya berkisar $16,482-83,626$ ppb dengan rerata $50,980 \mathrm{ppb}$ dan total 203,922 ppb. Data ini menunjukkan juga menunjukkan bulan Mei 2013 lebih sedikit menerima masukan limbah yang mengandung $B(a) P$ dibandingkan bulan Juli. 
Dari uraian di atas dapat dilihat bahwa air laut di Teluk Jakarta pada tahun 2011 lebih banyak menerima masukan limbah yang mengandung $\mathrm{B}(\mathrm{a}) \mathrm{P}$. Kadar $\mathrm{B}(\mathrm{a}) \mathrm{P}$ ini lebih tinggi dari kadar total PAH yang ditetap oleh KMNLH (2004) yakni 3 ppb dan nilai ambang batas yang ditetapkan untuk $\mathrm{B}(\mathrm{a}) \mathrm{P}$ yakni $0,01 \mathrm{ppb}$ (Nagpal, 2001), sedang DiToro et al., (2000) menetapkan nilai ambang batas $B(a) P$ sebesar 1,6 ppb. Senyawa ini merupakan salah satu senyawa PAH yang dilaporkan paling beracun bagi kehidupan laut. Contoh: Hasil uji bioassay menunjukkan EC50-72h B(a)P terhadap fitoplankton jenis Thalassiosira pseudonana adalah $55,24 \mu \mathrm{g} / \mathrm{L}$, konsentrasi ini menyebabkan $50 \%$ fitoplankton jenis ini akan mengalami kematian dalam waktu 72 jam (Boop et al., 2007). LC50-96h B(a)P terhadap larva fitoplankton jenis Palaemonetes pugio adalah $1.02 \mu \mathrm{g} / \mathrm{L}$ (Weinsten et al., 2008), data ini menunjukkan bahwa $50 \%$ larva plankton jenis ini akan mati pada kadar $\mathrm{B}(\mathrm{a}) \mathrm{P}$ sebesar $1,02 \mu \mathrm{g} / \mathrm{L}$ selang waktu $92 \mathrm{jam}$.

\section{Di-Benzo(a,h)Anthracene [Db(a,h)A]}

$\mathrm{Db}(\mathrm{a}, \mathrm{h})$ antrasen adalah senyawa $\mathrm{PAH}$ dengan berat molekul tinggi, mengandung 5 cincin benzen,merupakan polutan yang diprioritaskan oleh Environment Protection Agency (EPA), bersifat toksik, namun toksisitas akutnya jarang dilaporkan khususnya terhadap manusia, ikan, atau hewan lainnya. The Department of Health and Human Services (DHHS) menetapkan $\mathrm{Db}(\mathrm{a}, \mathrm{h}) \mathrm{A}$ perlu diantisipasi sebagai zat yang bersifat karsinogen. EPA juga menetapkan $\mathrm{Db}(\mathrm{a}, \mathrm{h}) \mathrm{A}$ termasuk zat yang dicurigai bersifat karsinogen terhadap manusia, masuk ke lingkungan akibat pembakaran yang tidak sempurna dari bahan-bahan organik. Hasil pengukuran $\mathrm{Db} \quad(\mathrm{a}, \mathrm{h}) \mathrm{A}$ di Teluk Jakarta disajikan pada Tabel 4 .<smiles></smiles>

\section{$\mathrm{Db}(\mathrm{a}, \mathrm{h})$ Antrasen}

Dari tabel 4. dapat dilihat pada bulan Maret 2013 kadar $\mathrm{Db}(\mathrm{a}, \mathrm{h}) \mathrm{A}$ di bagian barat Teluk Jakarta berkisar 1,128-3,722 ppb dengan rerata $2,370 \mathrm{ppb}$ dan total 9,483 ppb. Kadar ini lebih tinggi dibandingkan dengan bulan Maret 2011 yang kadar $\mathrm{Db}(\mathrm{a}, \mathrm{h}) \mathrm{A}$ nya adalah nol (tidak terdeteksi). Keadaan yang sebaliknya terjadi bulan Mei, dimana kadar $\mathrm{Db}(\mathrm{a}, \mathrm{h}) \mathrm{A}$ pada bulan Mei 2013 adalah nol (tidak terdeteksi), kadar ini lebih rendah dari bulan Juli 2011 yang kadar $\mathrm{Db}(\mathrm{a}, \mathrm{h}) \mathrm{A}$ nya berkisar $0,00-17,011$ ppb dengan rerata 6,892 ppb dan total 27,569 ppb.

Tabel 4. Kadar Db(a,h)Antrasen dalam Air Laut di Teluk Jakarta, ppb

\begin{tabular}{|c|c|c|c|c|c|c|c|c|}
\hline \multirow[t]{2}{*}{ St } & \multicolumn{2}{|c|}{$\begin{array}{c}\text { Bagian Barat } \\
2013\end{array}$} & \multirow[t]{2}{*}{ St } & \multicolumn{2}{|c|}{$\begin{array}{c}\text { Bagian Tengah } \\
2013\end{array}$} & \multirow[t]{2}{*}{ St } & \multicolumn{2}{|c|}{$\begin{array}{c}\text { Bagian Timur } \\
2013\end{array}$} \\
\hline & Maret & Mei & & Maret & Mei & & Maret & Mei \\
\hline 1 & 2,621 & 0,000 & 5 & 1,061 & 0,000 & 9 & 3,591 & 0,000 \\
\hline 2 & 1,128 & 0,000 & 6 & 2,125 & 0,000 & 10 & 0 & 0,000 \\
\hline 3 & 2,012 & 0,000 & 7 & 3,604 & 0,000 & 11 & 27,746 & 0,000 \\
\hline 4 & 3,722 & 0,000 & 8 & 4,072 & 0,000 & 12 & 3,512 & 0,000 \\
\hline Min & 1,128 & 0 & Min & 1,061 & 0 & Min & 0 & 0 \\
\hline Max & 3,722 & 0 & Max & 4,072 & 0 & Max & 27,746 & 0 \\
\hline StD & 1,089592 & 0 & StD & 1,380288 & 0 & StD & 12,79918 & 0 \\
\hline Rerata & 2,37075 & 0 & Rerata & 2,7155 & 0 & Rerata & 8,71225 & 0 \\
\hline
\end{tabular}




\begin{tabular}{|c|c|c|c|c|c|c|c|c|}
\hline \multirow{3}{*}{$\begin{array}{c}\text { Total } \\
\text { St }\end{array}$} & 9,483 & 0 & Total & 10,862 & 0 & Total & 34,849 & 0 \\
\hline & \multicolumn{2}{|c|}{$\begin{array}{c}\text { Bagian Barat } \\
2011\end{array}$} & St & \multicolumn{2}{|c|}{$\begin{array}{c}\text { Bagian Tengah } \\
2011\end{array}$} & St & \multicolumn{2}{|c|}{$\begin{array}{c}\text { Bagian Timur } \\
2011\end{array}$} \\
\hline & Maret & Juli & & Maret & Juli & & Maret & Juli \\
\hline 1 & 0,00 & 10,558 & 5 & 0,00 & 0,00 & 9 & 0,00 & 0,00 \\
\hline 2 & 0,00 & 17,011 & 6 & 0,00 & 0,00 & 10 & 0,00 & 0,00 \\
\hline 3 & 0,00 & 0,00 & 7 & 0,00 & 0,00 & 11 & 0,00 & 0,00 \\
\hline 4 & 0,00 & 0,00 & 8 & 0,00 & 0,00 & 12 & 0,00 & 0,00 \\
\hline Min & 0,00 & 0,00 & Min & 0,00 & 0,00 & Min & 0,00 & 0,00 \\
\hline Max & 0,00 & 17,011 & $\operatorname{Max}$ & 0,00 & 0,00 & Max & 0,00 & 0,00 \\
\hline StD & 0,00 & 8,383 & StD & 0,00 & 0,00 & StD & 0,00 & 0,00 \\
\hline Rerata & 0,00 & 6,892 & Rerata & 0,00 & 0,00 & Rerata & 0,00 & 0,00 \\
\hline Total & 0,00 & 27,569 & Total & 0,00 & 0,00 & Total & 0,00 & 0,00 \\
\hline $\begin{array}{c}\text { NAB B(a)P } \\
\text { NAB Total PAH }\end{array}$ & \multicolumn{8}{|c|}{$\begin{array}{c}0,6 \\
3\end{array}$} \\
\hline
\end{tabular}

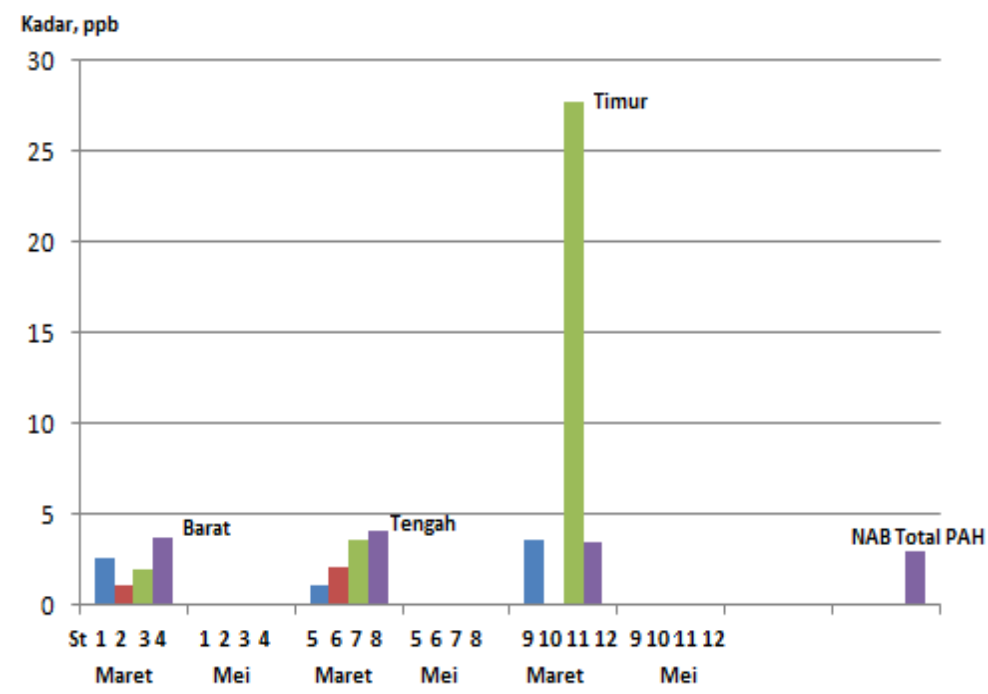

Gambar 7. Grafik Kadar Db(a,h)A pada bulan Maret dan Mei 2013

Di Teluk Jakarta bagian tengah pada bulan Maret kadar $\mathrm{Db}(\mathrm{a}, \mathrm{h}) \mathrm{A}$ berkisar 1,061-4,072 ppb dengan rerata 2,715 ppb dan total 10,862 ppb. Kadar ini lebih tinggi dari bulan Maret 2011 yang kadar DB(a,h)A nya adalah nol (tidak terdeteksi). Pada bulan Mei 2013 kadar $\mathrm{Db}(\mathrm{a}, \mathrm{h}) \mathrm{A}$ tidak berbeda dengan bulan Juli 2011 yakni nol (tidak terdeteksi di semua stasiun.

Pada bulan Maret 2013 di Teluk Jakarta bagian timur kadar $\mathrm{Db}(\mathrm{a}, \mathrm{h}) \mathrm{A}$ berkisar 0,00 $27,746 \mathrm{ppb}$ dengan rerata $8,712 \mathrm{ppb}$ dan total $34,849 \mathrm{ppb}$. Kadar ini lebih tinggi dari bulan Maret 2011 yang kadar $\mathrm{Db}(\mathrm{a}, \mathrm{h}) \mathrm{A}$ nya adalah nol (tidak terdeteksi). Pada bulan Mei 2013 kadar $\mathrm{Db}(\mathrm{a}, \mathrm{h}) \mathrm{A}$ tidak berbeda dengan bulan Juli 2011. Kadar $\mathrm{Db}(\mathrm{a}, \mathrm{h})$ pada kedua bulan tersebut adalah nol (tidak terdeteksi. Data ini menunjukkan bahwa perairan Teluk Jakarta pada tahun 2013 bulan Mei di bagian barat, tengah, dan timur relatif lebih bersih dari cemaran $\mathrm{Db}(\mathrm{a}, \mathrm{h}) \mathrm{A}$, demikian juga halnya dengan bulan Maret di Teluk Jakarta bagian barat, Maret dan Juli di bagian tengah dan timur 2011. Kadar $\mathrm{Db}(\mathrm{a}, \mathrm{h}) \mathrm{A}$ yang terdeteksi pada bulan Maret 2013 di bagian barat, tengah dan timur, serta pada bulan Juli 2011 di Teluk Jakarta bagian barat $p$ lebih tinggi dari kriteria yang ditetapkan KMNLH (2004) untuk perlindungan biota laut yakni $3 \mathrm{ppb}$ dan 0,6 ppb untuk individual $\mathrm{Db}(\mathrm{a}, \mathrm{h}) \mathrm{A}$ (DiToro et al., 2000).

\section{Benzo(g,h,i)Perylene, [B(g,h,i)]P}

$\mathrm{B}(\mathrm{g}, \mathrm{h}, \mathrm{i}) \mathrm{P}$ adalah senyawa Polisiklik Aromatik Hidrokarbon (PAH) dengan berat molekul tinggi dengan enam cincin benzen, dan dinyatakan oleh EPA sebagai polutan prioritas. Banyak sumber menyatakan bahwa senyawa ini tidak bersifat karsinogen terhadap makhluk hidup. Toksisitas akutnya jarang dilaporkan khususnya pada manusia, ikan, atau satwa liar, akibat terpapar senyawa ini. Badan Internasional untuk Penelitian Kanker (IARC) dan EPA menetapkan bahwa $\mathrm{B}(\mathrm{g}, \mathrm{h}, \mathrm{i}) \mathrm{P}$ tidak termasuk ke dalam kelompok zat yang bersifat karsinogen terhadap manusia. $\mathrm{B}(\mathrm{g}, \mathrm{h}, \mathrm{i}) \mathrm{P}$ 
adalah komponen dari minyak mentah dan produk pembakaran yang dapat diproduksi dan dilepaskan ke lingkungan selama kebakaran alami. Emisi dari penyulingan minyak bumi, tar batubara, dan pembakaran bahan bakar kayu, batu bara, minyak, propana, bensin dan diesel merupakan kontributor utama $\mathrm{B}(\mathrm{g}, \mathrm{h}, \mathrm{i}) \mathrm{P}$ ke lingkungan. $\mathrm{B}(\mathrm{g}, \mathrm{h}, \mathrm{i}) \mathrm{P}$ juga dapat lepas ke lingkungan melalui limbah industri, fasilitas pengolahan air limbah kota dan insinerator limbah, terurai secara perlahan di lingkungan. Biodegradasi $\mathrm{B}(\mathrm{g}, \mathrm{h}, \mathrm{i}) \mathrm{P}$ pada tanah aerobik berkisar $600-650$ hari. Nilai ambang batas $B(g, h, i) P$ untuk air dan ikan $0.0028 \mathrm{ug} / \mathrm{L}$. Hasil pengukuran $\mathrm{B}(\mathrm{g}, \mathrm{h}, \mathrm{i}) \mathrm{P}$ di Teluk Jakarta disajikan pada Tabel 5 .

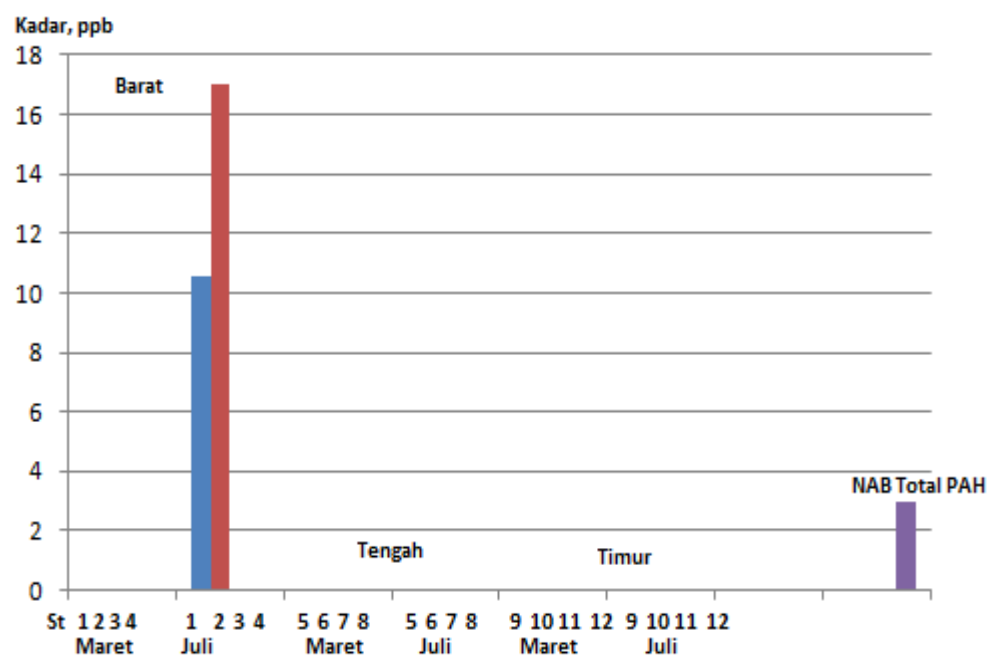

Gambar 8. Grafik Kadar Db(a,h)A pada bulan Maret dan Juli 2011<smiles></smiles>

Benzo(g,h,i)Perylen

Dari tabel tersebut dapat dilihat kadar $\mathrm{B}(\mathrm{g}, \mathrm{h}, \mathrm{i}) \mathrm{P}$ di Teluk Jakarta bagian barat pada bulan Maret 2013 berkisar 0,00-2,011 ppb dengan rerata 1,073 dan total 4,293 ppb. Kadar ini lebih rendah bila dibandingkan dengan kadar $\mathrm{B}(\mathrm{g}, \mathrm{h}, \mathrm{i}) \mathrm{P}$ pada bulan Maret
2011. Kadar B(g,h,i)P pada bulan Maret 2011 berkisar 14,01-26,01 dengan rerata 19,405 ppb dan total $77,62 \mathrm{ppb}$. Data ini menunjukkan bulan Maret 2011 lebih banyak menerima masukan limbah yang mengandung $B(g, h, i) P$ dibandingkan bulan Maret 2013.

Tabel 5. Kadar B(ghi)Perylen dalam Air Laut di Teluk Jakarta, ppb

\begin{tabular}{|c|c|c|c|c|c|c|c|c|}
\hline \multirow[t]{2}{*}{ St } & \multicolumn{2}{|c|}{$\begin{array}{c}\text { Bagian Barat } \\
2013\end{array}$} & \multirow[t]{2}{*}{ St } & \multicolumn{2}{|c|}{$\begin{array}{c}\text { Bagian Tengah } \\
2013\end{array}$} & \multirow[t]{2}{*}{ St } & \multicolumn{2}{|c|}{$\begin{array}{c}\text { Bagian Timur } \\
2013\end{array}$} \\
\hline & Maret & Mei & & Maret & Mei & & Maret & Mei \\
\hline 1 & 1,149 & 0,000 & 5 & 0 & 0,000 & 9 & 2,847 & 0,000 \\
\hline 2 & 0 & 0,000 & 6 & 0,988 & 0,000 & 10 & 3,540 & 1,693 \\
\hline 3 & 1,133 & 0,000 & 7 & 4,464 & 0,000 & 11 & 16,298 & 0,000 \\
\hline 4 & 2,011 & 0,000 & 8 & 3,056 & 0,000 & 12 & 3,405 & 0,000 \\
\hline Min & 0 & 0 & Min & 0 & 0 & Min & 2,847 & 0 \\
\hline Max & 2,011 & 0 & Max & 4,464 & 0 & Max & 16,298 & 1,693 \\
\hline
\end{tabular}


Edward, Pengukuran Kadar Senyawa Polisiklik Aromatik Hidrocarbon

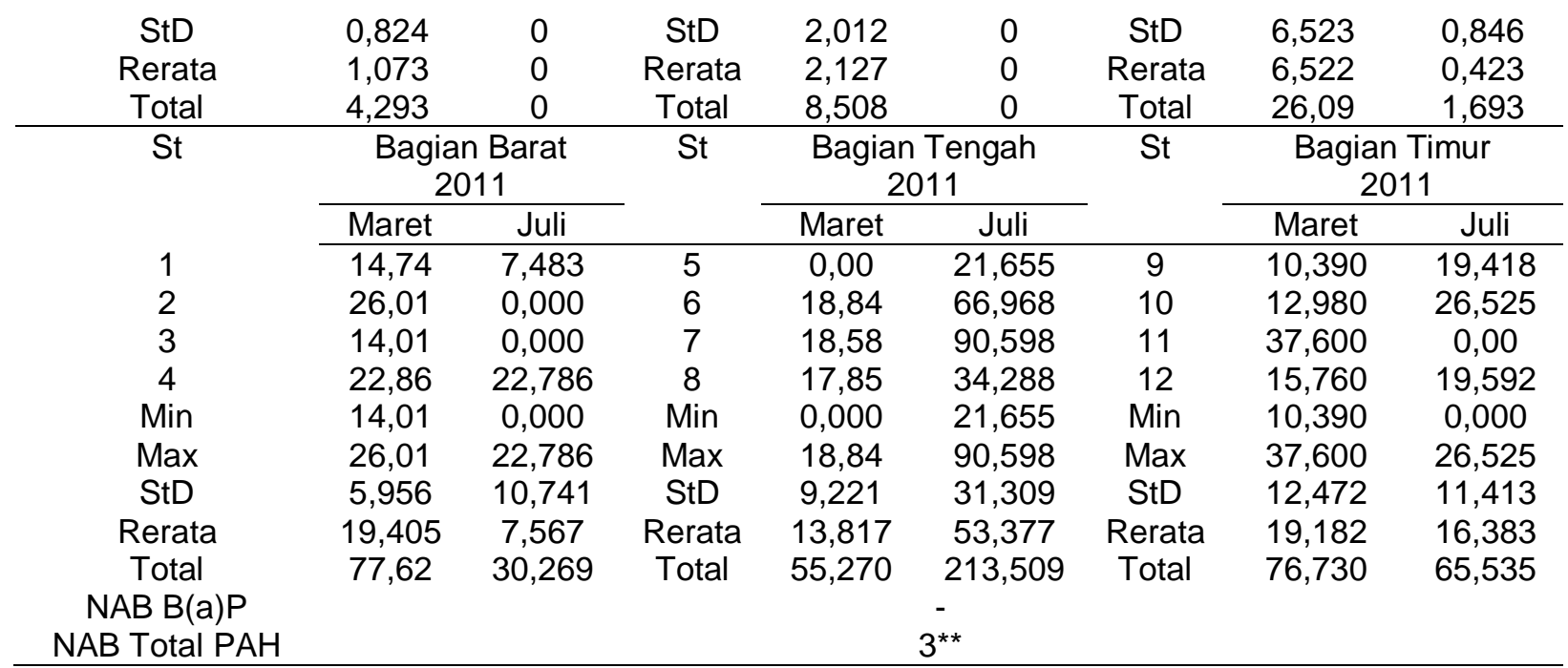

Pada bulan Mei di Teluk Jakarta bagian barat kadar $\mathrm{B}(\mathrm{g}, \mathrm{h}, \mathrm{i}) \mathrm{P}$ disemua stasiun adalah nol (tidak terdeteksi). Kadar ini lebih rendah dari bulan Juli 2011 yang kadar $\mathrm{B}(\mathrm{g}, \mathrm{h}, \mathrm{i}) \mathrm{P}$ nya berkisar 0,00-22,786 ppb dengan rerata 30,269 ppb. Data ini menunjukkan bulan Juli 2011 lebih banyak menerima masukan limbah yang mengandung $\mathrm{B}(\mathrm{g}, \mathrm{h}, \mathrm{i}) \mathrm{P}$ dibandingkan dengan bulan Mei 2013.

Di Teluk Jakarta bagian tengah pada bulan Maret 2013, kadar B(g,h,i)P berkisar 0,00$4,464 \mathrm{ppb}$ dengan rerata 2,127 ppb dan total $8,508 \mathrm{ppb}$. Kadar ini juga lebih rendah dibandingkan dengan bulan Maret 2011 yang kadar $\mathrm{B}(\mathrm{g}, \mathrm{h}, \mathrm{i}) \mathrm{P}$ nya berkisar $0,00-18,84 \mathrm{ppb}$ dengan rerrata $13,817 \mathrm{ppb}$ dan total 55,270 ppb. Pada bulan Mei kadar B(g,h,i)P di semua stasiun adalah nol (tidak terdeteksi), kadar ini juga lebih rendah bila dibandingkan dengan bulan Juli 2011 yang kadar $\mathrm{B}(\mathrm{g}, \mathrm{h}, \mathrm{i}) \mathrm{P}$ nya berkisar 21,655-90,598 ppb dengan rerata $53,377 \mathrm{ppb}$ dan total $213,509 \mathrm{ppb}$.

Pada bulan Maret 2013, kadar B(g,h,i)P di Teluk Jakarta bagian timur berkisar 2,847$16,928 \mathrm{ppb}$ dengan rerata $6,522 \mathrm{ppb}$ dan total 26,09 ppb. Kadar ini juga lebih rendah dibandingkan bulan Maret 2011 yang kadar $\mathrm{B}(\mathrm{g}, \mathrm{h}, \mathrm{i}) \mathrm{A}$ nya berkisar 10,390-37,600 ppb dengan rerata $19,182 \mathrm{ppb}$ dan total 76,730 ppb.

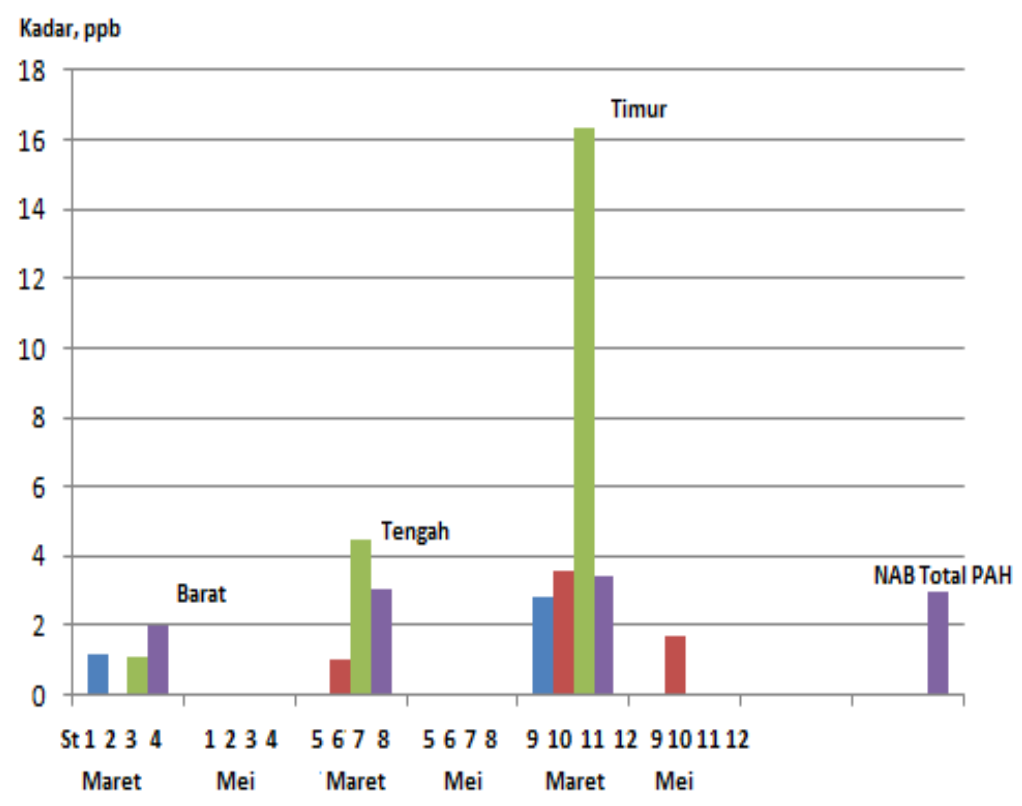

Gambar 9. Grafik Kadar B(g,h.i)P pada bulan Maret dan Mei 2013

Pada bulan Mei 2013, kadar B(g,h,i)P di Teluk Jakarta bagian barat berkisar 0,0-1,693 ppb dengan rerata $0,423 \mathrm{ppb}$ dan total 1,693 ppb. Kadar ini lebih rendah dibandingkan dengan 
bulan Juli 2011 yang kadar $B(g, h, i) A$ nya berkisar $0,00-26,525 \mathrm{ppb}$ dengan rerata $16,383 \mathrm{ppb}$ dan total $65,535 \mathrm{ppb}$. Data ini menunjukkan bulan Maret dan Mei 2013 menerima masukan limbah yang menagndung $\mathrm{B}(\mathrm{g}, \mathrm{h}, \mathrm{i}) \mathrm{A}$ lebih sedikit dibandingkan dengan bulan Maret dan Juli 2011.

Secara keseluruhan dapat dilihat kadar ke lima senyawa $\mathrm{PAH}$ tersebut lebih tinggi dibandingkan dengan kriteria yang ditetapkan oleh KMNLH (2004) untuk perlindungan biota laut yakni $3 \mathrm{ppb}$, kecuali $\mathrm{B}(\mathrm{g}, \mathrm{h}, \mathrm{i}) \mathrm{P}$ hanya dua stasiun yang telah melewati NAB, sedang stasiun lainnya nol (tidak terdeteksi). Pemerintah Kanada memberikan nilai ambang batas aman untuk $\mathrm{B}(\mathrm{a}) \mathrm{P}$ dan $\mathrm{B}(\mathrm{a}) \mathrm{A}$ masingmasing adalah $0,018 \mathrm{ppb}$ dan $0,015 \mathrm{ppb}$ untuk perlindungan biota akuatik (CCME, 2010). Kadar ke lima senyawa PAH tersebut lebih tinggi dari nilai ambang batas yang aman untuk perlindungan biota laut. Hal ini bisa membahayakan biota laut yang hidup di perairan ini.

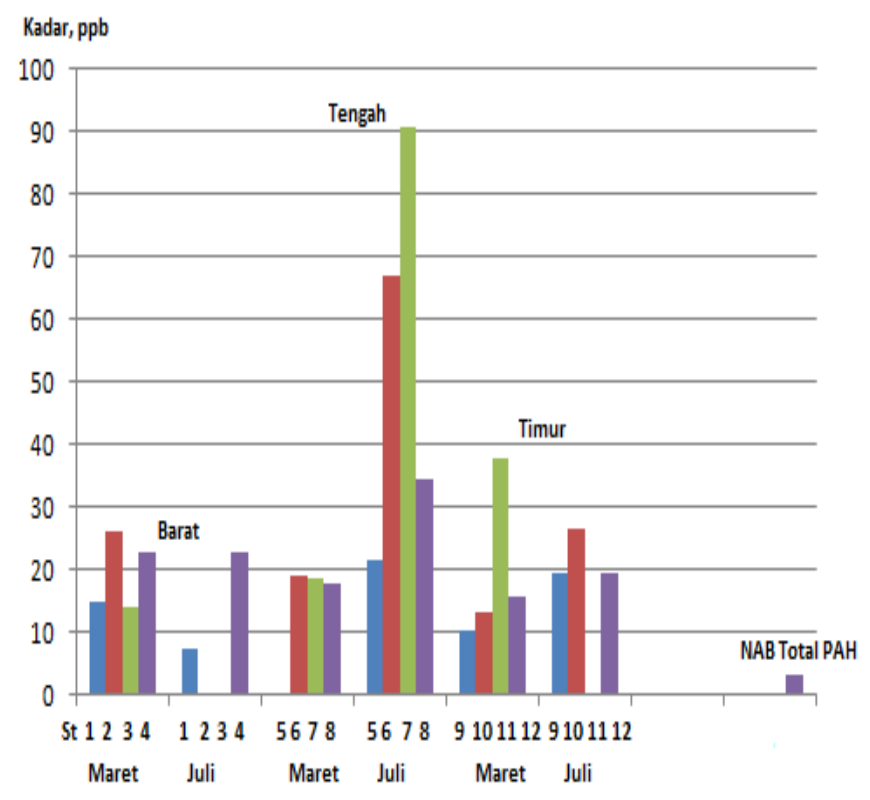

Gambar 10. Grafik Kadar B(g,h.i)P pada bulan Maret dan Juli 2011

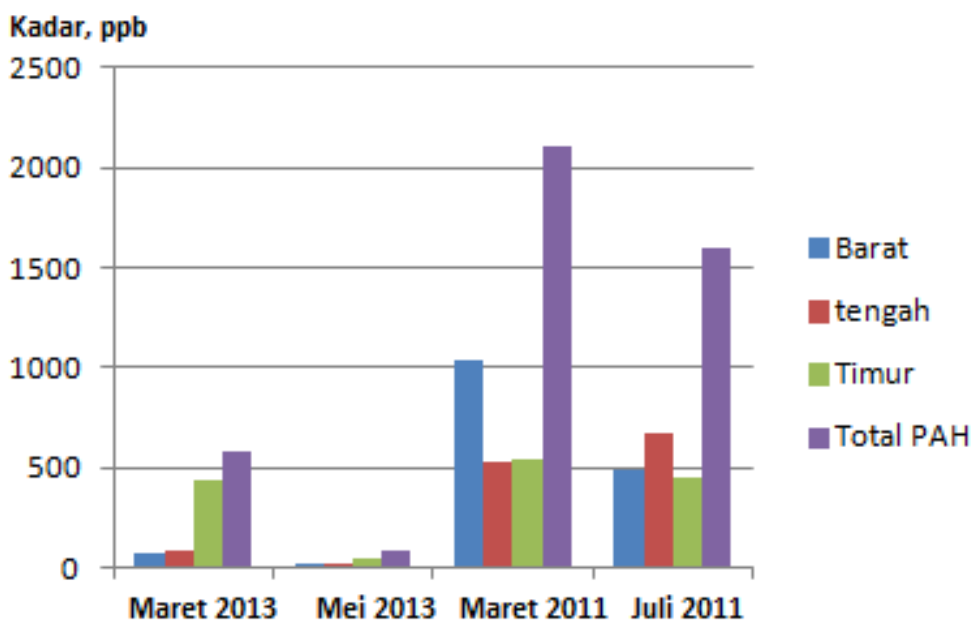

Gambar 11. Grafik Kadar B(g,h.i)P pada bulan Maret dan Mei 2013, Maret dan Juli 2011

Bila diamati untuk masing-masing lokasi dan bulan pengamatan terlihat bahwa pada bulan Maret 2013 kadar senyawa $B(a) A, B(b) F$, $\mathrm{B}(\mathrm{a}) \mathrm{P}, \quad \mathrm{Db}(\mathrm{a}, \mathrm{h}) \mathrm{A}, \quad$ dan $\mathrm{B}(\mathrm{g}, \mathrm{h}, \mathrm{i}) \mathrm{P}$ tertinggi ditemukan di bagian timur, selanjutnya tengah dan barat, pada bulan Mei tertinggi ditemukan di bagian timur, barat dan tengah. Pada bulan Maret 2011, kadar tertinggi dijumpai di bagian barat, timur dan tengah, pada bulan Juli kadar tertinggi dijumpai di bagian tengah, barat, dan 
timur. Data ini menunjukkan kadar kelima senyawa $\mathrm{PAH}$ tersebut sangat bervariasi sesuai dengan waktu pengamatan. Secara total kadar ke lima senyawa PAH tersebut tertinggi dijumpai pada bulan Maret 2011, selanjutnya Juli 2011, Maret 2013, dan Mei 2013. Data ini menunjukkan bahwa bulan Mei 2013 relatif lebih bersih dari limbah yang mengandung kelima senyawa PAH tersebut.

Tabel 6. Total Kadar B(a)A, B(b)F, B(a)P, Db(a)A, B(g,h,i)P dalam Air laut di Teluk Jakarta

\begin{tabular}{ccccc}
\hline Teluk Jakarta & \multicolumn{4}{c}{ Total B(a)A, B(b)F, B(a)P, Db(a)A, B(g,h,i)P, ppb } \\
\hline & Maret 2013 & Mei 2013 & Maret 2011 & Juli 2011 \\
\cline { 2 - 5 } Barat & 68,144 & 21,677 & 1032,190 & 486,470 \\
Tengah & 81,587 & 21,52 & 523,490 & 666,886 \\
Timur & 431,525 & 41,165 & 547,370 & 451,135 \\
Total PAH & 581,256 & 84,362 & 2103,05 & 1604,491 \\
NAB Total PAH & & 3 & \\
\hline
\end{tabular}

\section{KESIMPULAN DAN SARAN}

Berdasarkan data yang dikaji dapat disimpulkan sebagai berikut; Senyawa $B[a] A$, $\mathrm{B}[\mathrm{b}] \mathrm{F}, \mathrm{B}[\mathrm{a}] \mathrm{P}, \mathrm{Db}[\mathrm{a}, \mathrm{h}] \mathrm{A}$, dan $\mathrm{B}[\mathrm{g}, \mathrm{h}, \mathrm{i}] \mathrm{P}$ dalam air laut di Teluk Jakarta telah melebihi nilai ambang batas aman bagi biota laut. Total kadar kelima senyawa tersebut pada Maret lebih tinggi dibandingkan bulan Mei dan Juli.

\section{DAFTAR PUSTAKA}

Alawi, M. A., \& Azeez, A. L. (2016). Study of polycyclic aromatic hydrocarbons (PAHs) in soil samples from Al-Ahdab oil field in Waset Region, Iraq. Toxin Reviews, 35(3-4), 69-76.

Ahmad, F. (2012). Kandungan Senyawa Polisiklik Aromatik Hidrokarbon (PAH) di Teluk Jakarta (Polycyclic Aromatic Compounds Hydrocarbons (PAH) Content in Jakarta Bay). ILMU KELAUTAN: Indonesian Journal of Marine Sciences, 17(4), 199-208.

Almeda, R., Zoe Wambaugh., Chao Chai., Zucheng Wang., Zhanfei Liu., Edward J. Buskey. (2013). Effects of Crude Oil Exposure on Bioaccumulation of Polycyclic Aromatic Hydrocarbons and Survival of Adult and Larval Stages of Gelatinous Zooplankton. LoS ONE 8(10), 1-15.

Bopp, S. K and Lettieri T. (2007). Gene regulation in the marine diatom Thalassiosira pseudonana upon exposure to polycyclic aromatic hydrocarbons (PAHs). Gene, 396(2), 293-302.

C.J. Igwe and Ikaogo, P.O. (2015). Environmental Effects of Polycyclic Aromatic Hydrocarbons. Journal of Natural Sciences Research, 5(7), 117132
CCME (Canadian Council of Ministers of the Environment). (2010). Canadian Soil Quality Guidelines for the Protection of Environmental and Human Health: Carcinogenic and Other PAHs. Available from: http://www. ccme.ca/en/resources/ canadi an environmental quality-guide lines /scientific_supporting__docume nts .htm

Dong, C., Bai, X., Sheng, H., Jiao, L., Zhou, H., \& Shao, Z. (2015). Distribution of $\mathrm{PAHs}$ and the PAH-degrading bacteria in the deep-sea sediments of the highlatitude Arctic Ocean. Biogeosciences, 12(7), 2163-2177.

Duinker, J. C. J. HILLERBRAND (1978). Determination of selected organochlorine seawater. Methods of Seawater Analysis Verlag Cheme. Weinheim, 290-304.

Di Toro, D.M., J.A. McGrath, and D.J. Hansen, 2000. Technical basis for narcotic chemicals and polycyclic aromatic hydrocarbon criteria. I. Water and tissue. Environ. Toxicol. Chem. 19, 1951-1970.

Environment Canada. (1998). Canadian water quality guidelines for polycyclic aromatic hydrocarbons. Supporting document. Environment Canada, Environmental Quality Branch, Ottawa. Unpub. draft doc.

Greve, P. A., \& Grevenstuk, W. B. F. (1975). A convenient small-scale clean-up method for extracts of fatty samples with basic alumina before GLCanalysis on organochlorine pesticide residues. Rijksuniversiteit Faculteit Landbouwwetenschappen, Gent. 40, 1115-1124

Holden. A.V. and K.Marsden 1969. Single stage clean-up of animal tissue extracts for organochlorine residue 
analysis. Journal of Chrotography, 44, 481-492.

Irwin, R. J., Van Mouwerik, M., Stevens, L., Seese, M. D., \& Basham, W. (1997). Environmental Contaminants Encyclopedia. National Park Service, Water Resources Division, Fort Collins, Colorado. Distributed Within the Federal Government as an Electronic Document.

Kantor, M. N. L. H. (2004). Keputusan Menteri Negara dan Lingkungan Hidup No. Kep-51/2004 Tentang Pedoman Penetapan Baku Mutu Air Laut. Kantor Menteri Negara Kependudukan dan Lingkungan Hidup, Jakarta.

Mirza, R., Faghiri, I., \& Abedi, E. (2012). Contamination of polycyclic aromatic hydrocarbons in surface sediments of Khure-Musa Estuarine, Persian Gulf. World Journal of fish and marine sciences, 4(2), 136-141.

Nagpal, N. K. (1993). Ambient water quality criteria for polycyclic aromatic hydrocarbons (PAHs). BC Environment, Water Quality Branch.

NRC (2003). Oil in the sea III: inputs, fates, and effects, Washington, DC.
Syakti, A. D. (2016). Molecular Diagnostic Ratios To Assess The Apportionment Of Petroleum Hydrocarbons Contaminantion In Marine Sediment. Molekul, 11(2), 208-219.

Stogiannidis, E., \& Laane, R. (2015). Source characterization of polycyclic aromatic hydrocarbons by using their molecular indices: an overview of possibilities. In Reviews of environmental contamination and toxicology (pp. 49133). Springer International Publishing.

Weinstein, J. E., \& Garner, T. R. (2008). Piperonyl butoxide enhances the bioconcentration and photoinduced toxicity of fluoranthene and benzo [a] pyrene to larvae of the grass shrimp (Palaemonetes pugio). Aquatic toxicology, 87(1), 28-36.

Zaghden, H., Kallel, M., Elleuch, B., Oudot, J., Saliot, A. (2007), Sources and distribution of aliphatic and polyaromatic hydrocarbons in sediments of Sfax, Tunisia, Mediterranean Sea. Marine Chemistry, 105(1-2), 70-89. 